\title{
Choice of conditions for human bone marrow stromal cells seeding into polymer macroporous sponges
}

\author{
Yu. A. Petrenko, N. A. Volkova, E. P. Zhulikova, L. G. Damshkaln', V. I. Lozinsky',
}

A. Yu. Petrenko

A.N.Nesmeyanov Institute of Organoelement Compounds Russian Academy of Sciences Vavilova str. 28, 119991, Moscow, Russia

${ }^{1}$ Institute for Problems of Cryobiology and Cryomedicine NAS of Ukraine

23, Pereyaslavskaya str., Kharkov, Ukraine 61015

yuripetrenko@cryo.org.ua

\begin{abstract}
Different conditions of seeding human bone marrow stromal cells (SC) into polymer sponges based on macroporous agarose cryogel (MACG) were investigated. Three methods of cell seeding into MACG were used: co-incubation with permanent stirring, intensive shaking and creation of negative pressure. The results obtained show a considerable potential of macroporous agarose cryogel sponges as a three-dimensional carrier for cultivating stromal cells at different methods of cell seeding.
\end{abstract}

Keywords: tissue engineering, bone marrow stromal cells, macroporous sponges, agarose cryogel, seeding, Alamar Blue.

Introduction. Tissue engineering is a young filed of biotechnology, based on the principles of biology, chemistry, material science and medicine. Studies in this field include the application of complex of cells and biomaterials of various characters in order to create tissues, functioning in vitro for further transplantation. The materials, based on agarose (polysaccharide, obtained from marine algae), do not dissociate in the mammal organisms because of the absence of agarolytic enzymes. Thus it can ensure a long-term shape and volume maintenance of transplant created using agarose as a carrier of corresponding cells. Furthermore, agarose does not induce xenogenic immune response, and agarose gel ensures the proliferation of embryonic and hematopoietic stem cells as well as some other cell lines

(C) Yu. A. PETRENKO, N. A. VOLKOVA, E. P. ZHULIKOVA, L. G. DAMSHKALN, V. I. LOZINSKY, A. Yu. PETRENKO, 2008 in the culture $[1,2]$. To create bioengineered constructions the pores inside of 3D carrier should be interconnecting, of optimal size for cell inoculation and enough area for their further growth. The macroporous cryogels based on agarose satisfy these requirements [3].

The polymerous cryogels are high-porosity gel materials, generally formed in superficially frozen medium. The generated polycrystals of solvent function as porogen, and gel-matrix itself originates in system regions, remaining liquid (in co-called liquid microphase) [4]. Therefore, a typical morphological feature of the cryogels is their macroporosity, and since every crystal of freezing solvent grows up to the intimate contact with another crystal face the macropores after defrosting are interconnected in generated gel material.

Stem cells attract special attention as a biological component of bioengineered constructions. These cells can be maintained in undifferentiated state and then 
induced to differentiate in definite direction. Mesenchymal stem cells (MSC) capable to differentiate into cartilaginous, muscular, bone and adipose tissues are an optimal cellular material for the development of bioengineered constructions of various types of connective tissue [5]. We have recently shown [6] that after monolayer cultivation in selective medium the adult bone marrow stromal cells (SC) are characterized by the properties of MSC (clonogenic growth, multilineage differentiation, appropriate immunophenotype). Thereby these cells have been selected as cellular component for seeding into macroporous sponges, based on the agarose cryogel.

An adequate method of the carrier seeding has to be chosen to ensure the uniform cell distribution and provision of their proliferation in 3D structures. There are various methods of cell injection into a sponge-carrier, though, the application of "vacuum seeding" [7, 8], joint cell and carrier incubation [9] and intensive shaking $[10,11]$ showed the best seeding and uniform distribution in the bulk of macroporous carrier. However, until the present time no studies have been carried out on the comparison of seeding methods and selection of the optimal way to seed MSC into the macroporous sponges for the development of bioengineered construction of the connective tissue.

The aim of this study was to investigate the peculiarities of bone marrow SC seeding into the polymerous sponges, based on the macroporous agarose cryogel, using different methods of cell injection.

Material and methods.Isolation and cultivation of bone marrow stromal cells. Bone marrow cell suspension was obtained by washing out of spongy iliac crest biopsy with medium M199. The cell suspension was centrifuged at $150 \mathrm{~g}$ for 10 minutes and resuspended in the Dulbecco's modified Eagles medium (DMEM) contained $15 \%$ of fetal bovine serum, penicillin (50 units $/ \mathrm{ml})$, streptomycin $(50 \mathrm{mg} / \mathrm{ml})$ and L-glutamine (2 $\mathrm{mM} / \mathrm{ml}$ ). The cells were cultured at $37^{\circ} \mathrm{C}, 5 \% \mathrm{CO}_{2}$ and $95 \%$ humidity. The medium was replaced after cultivating for 72 hours and then every 3-4 days. After monolayer growth had reached $70 \%$, an adhesive cell fraction was removed from the culture plastic with a mixture of trypsin/versen (1:4) and subcultured in 1:3 ratio [12]. The study was approved by the ethic commission of Institution of Problems of Cryobiology and Cryomedicine NASU.

Immunophenotype study. The $4^{\text {th }}$ passage cells were stained with FITC- or PE-conjugated monoclonal antibodies CD29, CD34, CD44, CD45, CD73 and CD105 and then analyzed using flow cytometer FACS Calibur ("BD Biosciences", USA) in order to define their immunophenotype. The data were processed using the WinMDI software and represented as histograms.

The preparation of macroporous substrates for three dimensional culture of bone marrow stromal cells. The agarose cryogel was obtained according to [3] from agarose with further polysaccharide base activation by divinylsulfon and covalent binding of gelatin to the macropores surface as in [13]. With this purpose a hot $\left(55^{\circ} \mathrm{C}\right) 3 \%$ aqueous solution of agarose Type VII-A (Low Gelling Temperature, "Sigma", USA), titrated quickly up to $\mathrm{pH} 12.6$ with $1 \mathrm{~N}$ solution of $\mathrm{NaOH}$, was poured out onto a metal (stainless steel) pan. This pan was installed strictly(gorisontal'no) into the chamber of precision programmable refrigerator FP 45 HP ("Julabo", Germany). A sample was frozen down to $-30^{\circ} \mathrm{C}$ for 30 minutes, then hold for 18 hours at $-5^{\circ} \mathrm{C}$ and thawed at $20^{\circ} \mathrm{C}$. The agarose cryogel obtained was washed with water down to neutral $\mathrm{pH}$ and then this spongy material was cut into the discs of $2 \mathrm{~mm}$ thickness and $10 \mathrm{~mm}$ diameter. The discs were treated with 100 -fold divinylsulfon redundancy ("Aldrich", USA) in $1 \mathrm{M}$ solution of $\mathrm{Na}_{2} \mathrm{CO}_{3}$ under room temperature for 20 hours. Reagents were washed out with water and discs were loaded in warm $\left(40^{\circ} \mathrm{C}\right) 2 \%$ solution of type A gelatin ("Sigma", USA) for 6 hours. Then discs were flushed with large amount of water, hold for 2 hours in 1 M TRIS solution and finally flushed with water down to the neutral $\mathrm{pH}$ of medium. The amount of coupled gelatin was $0.5-0.8$ milligrams of protein per 1 gram of damp macroporous agarose cryogel (MACG) [13]. Prepared discs were kept in $70 \%$ ethanol for further applications.

MACG seeding with bone marrow stromal cells. Spongy MACG-discs were put into the round-bottomed tubes with culture medium and hold at $37^{\circ} \mathrm{C}$ for twenty-four hours. Then the $4^{\text {th }}$ passage bone marrow SC were loaded into the flasks containing MACG in the final concentration of $5 \times 10^{5}$ cells in $1 \mathrm{ml}$. 

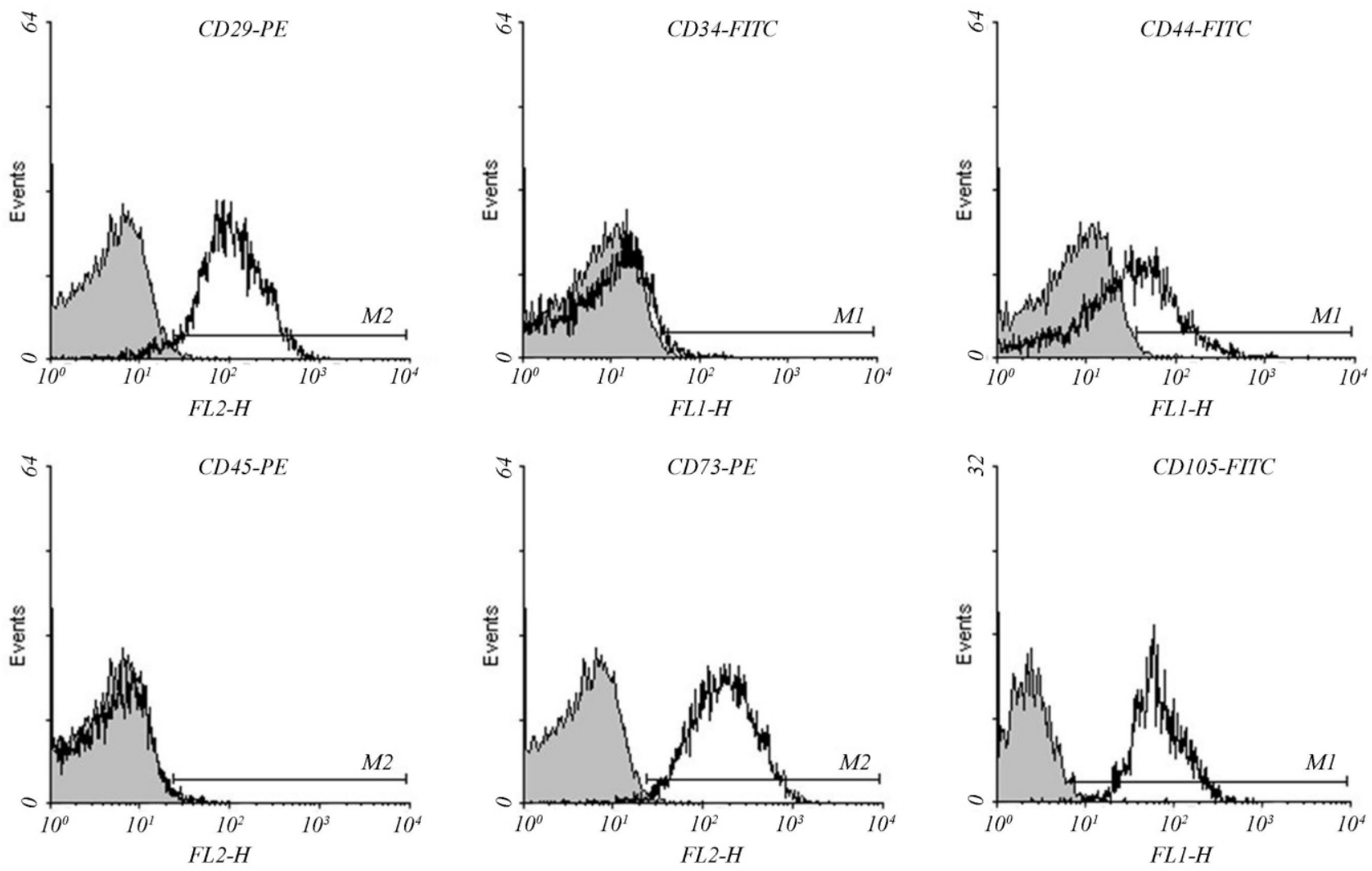

Fig.1. Immunophenotype of $4^{\text {th }}$ passage bone marrow stromal cells

Three variants of SC seeding into spongy MACG have been used:

- Variant 1 - "incubation": the suspension of bone marrow SC was incubated in the tubes with MACG under room temperature and constantly stirred at 200 rpm for 3 hours.

-Variant 2 - "shaking": the tubes with suspension of bone marrow SC were intensively shaken with vortex mixer at $1500 \mathrm{rpm}$ for 1 minute and then loaded into the incubator at $37^{\circ} \mathrm{C}$ for 3 hours.

-Variant 3 - "vacuum seeding": in the tubes with cells and MACG a negative pressure was created by pumping out residual air with a syringe with further loading them into an incubator for 3 hours.

After 3 hours incubation MACG discs, which contained cells, were replaced into wells of 24 well plate for further cultivation. The residual cells were taken from tubes into the Goryaev chamber and counted. The efficiency of bone marrow SC injection into the 3D MACG matrices was calculated by a difference between the cells amounts in the initial suspension and after injection into MACG, against the initial quantity of cells.

Study on metabolic and proliferative activity of bone marrow SC, cultured within the MACG discs. The metabolic and proliferative activities of bone marrow stromal cells, cultured within MACG discs, were estimated using REDOX-indicator Alamar Blue (AB). In order to do this $10 \%$ of $\mathrm{AB}$ was added into the medium on $1^{\text {st }}, 4^{\text {th }}$ and $7^{\text {th }}$ days of culturing. After 2 hours the AB-containing medium was removed and its AB-reduction level was estimated using microplate spectrofluorimeter Tecan GENios with the excitation wave $550 \mathrm{~nm}$ and emission $590 \mathrm{~nm}$. The data were represented as a difference between experimental and background (without cells) samples and evaluated in Relative Fluorescent Units (RFU).

Histological research. In order to ascertain MACG architectonics, the sections of 10-50 $\mu \mathrm{m}$ thickness were obtained in cryostat microtome at $-15^{\circ} \mathrm{C}$. In some cases 


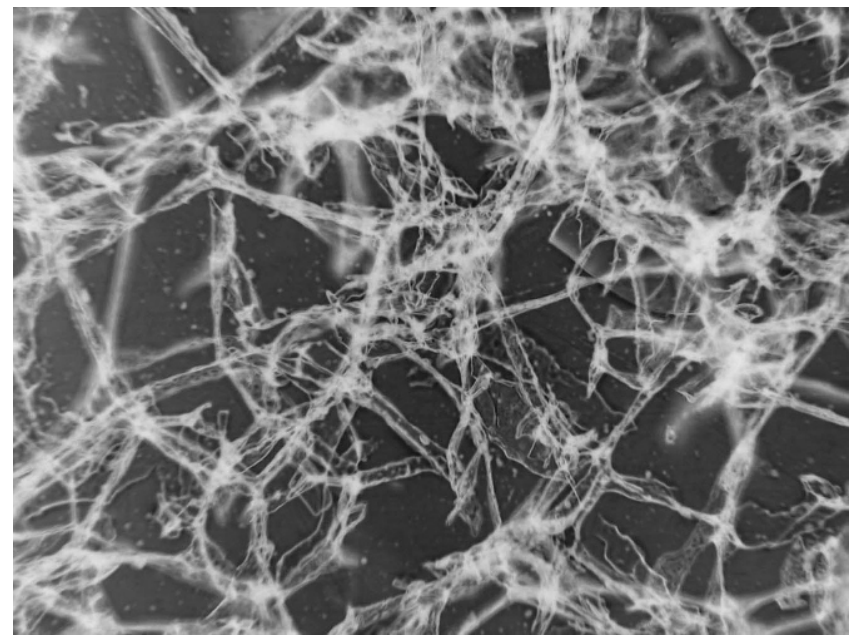

Fig.2. The structure of MACS (magn. $10 \times 10$ )

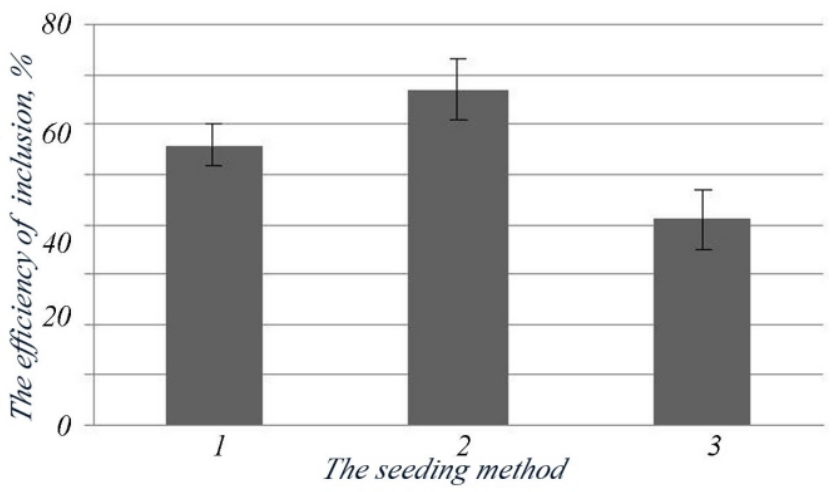

Fig.3. The efficiency of bone marrow stromal cells inclusion into MACS (numbers under bars correspond to the seeding method) The difference between the values presented is significant $(\mathrm{p}<0.05)$

the obtained histological sections were fixed in $70 \%$ alcohol, then stained with azur-eosin (Giemsa) and studied under an optical microscope.

Statistical analysis. The results obtained were statistically processed using Student's t-test. The data were represented as $\mathrm{M} \pm \mathrm{m}$, where $\mathrm{M}$ is an average value and $\mathrm{m}$ - a standard deviation.

Results and discussion. The bone marrow cells were cultivated under monolayer conditions, as described previously in [12]. During the bone marrow cells subculture the heterogeneity of adhesive cells seeding decreased and on the $4^{\text {th }}$ passage most of cells had fibroblast-like morphology.

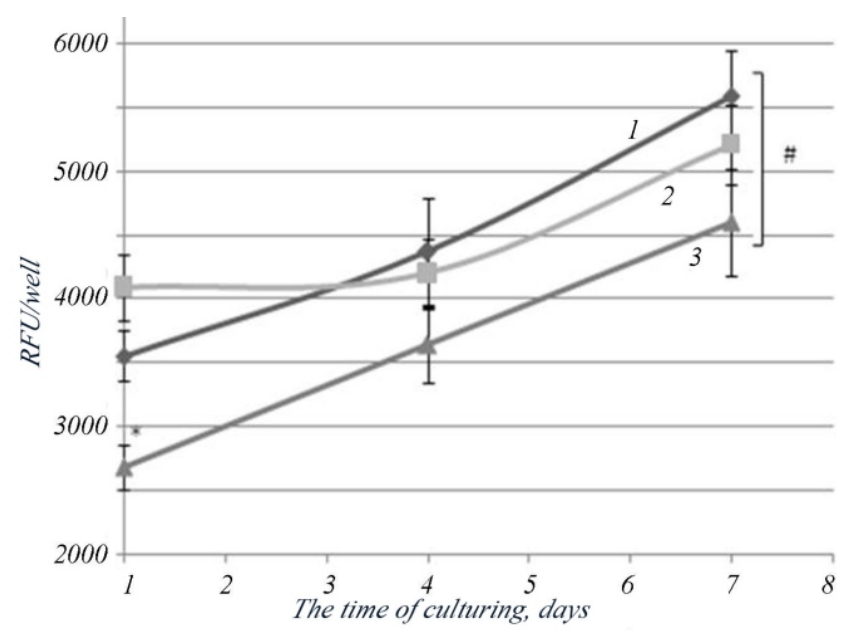

Fig. 4. The influence of different methods of bone marrow stromal cell seeding into MACS on the reduction level of AB during culturing (RFU/well): curves 1-3 - methods of cell seeding; * data is significantly different compared to methods 1 and $2(\mathrm{p}<0.05)$; \# values are significantly different compared to the 1 st day of culturing $(\mathrm{p}<0.05)$

After the $4^{\text {th }}$ passage SC were detached from the cell culture plastic and used for immunophenotype analysis and MACG-discs seeding. A phenotypic analysis showed that the bone marrow $\mathrm{SC}$ do not express hematopoietic markers (CD34 and CD35) and positively response to the antigens CD29, CD44, CD105 and CD73 (fig.1).

The data, presented above, show that the bone marrow SC, used to populate MACG-discs, have a typical for MSC phenotype [5, 14].

The study on the MACG-discs architectonics with the application of histological sections, showed that 3D carriers had ramified macroporous structure with pores section from 50 to $250 \mu \mathrm{m}$ (see inset, fig. 2). Such macropore size is quite enough for cells penetration into the carrier volume as well as for free substrate diffusion towards the cells and removal of their metabolites.

The study on efficiency of SC injection into the spongy MACG-discs showed that using the $1^{\text {st }}$ method of cell inoculation $56 \pm 4 \%$ of bone marrow SC attached to MACG (fig. 3).

The application of the $2^{\text {nd }}$ method allowed to increase slightly the number of cells, attached to MACG. The $3^{\text {rd }}$ variant appeared less efficient - in the incubation medium more than a half of cells remained 


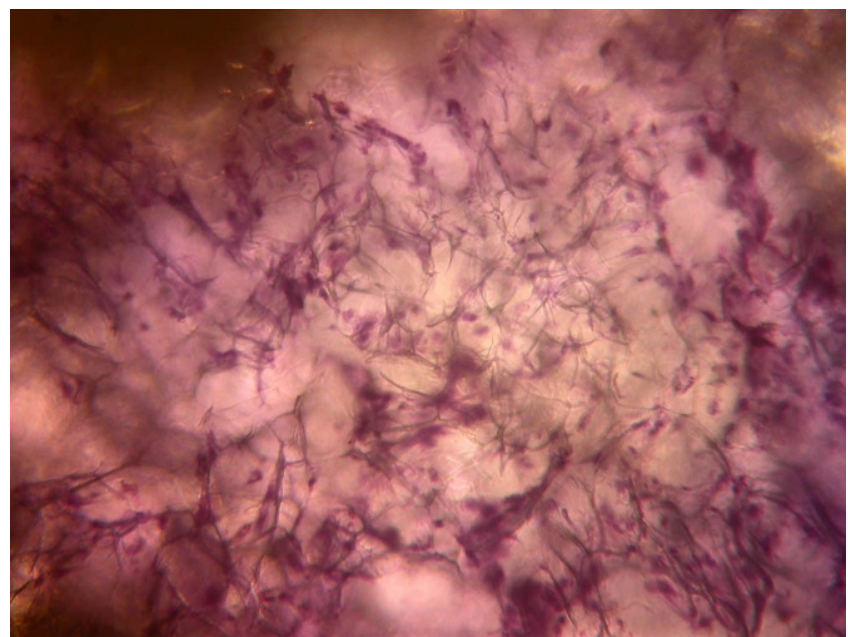

Fig.5. Histological section of MACS disk with seeded bone marrow stromal cells, 7 th day of culturing (Giemsa staining, magn. 4 x 10)

and the efficiency of cell injection into MACG was $41 \pm$ $6 \%$.

During the cultivation metabolic and proliferative activity of stromal cells within the MACG-discs was assessed by the $\mathrm{AB}$ reduction level (fig. 4). From the figure 4 it is seen that after 24 hours the reduction level of AB was the highest ( $4094 \pm 255$ RFU per well) using the $2^{\text {nd }}$ variant of cell injection into the carrier. Using the $1^{\text {st }}$ variant $\mathrm{AB}$ reduction level was lower $(3559 \pm 198$ RFU per well). The lowest AB-fluorescence level was achieved using the $3^{\text {rd }}$ variant of cell injection, this value significantly differed from the others and made up only $2684 \pm 175$ RFU per well.

The AB-reduction level increased during culturing and on the $7^{\text {th }}$ day there was no significant difference between any method of the cell inoculation. At the same time the dynamics of AB-reduction depended on the variants of injection applied. Using the seeding methods 1 and 3 the $\mathrm{AB}$ reduction level linearly increased during the cultivation. Simultaneously when using the $2^{\text {nd }}$ variant the $A B-r e d u c t i o n$ level did not change for 4 days of cultivation and increased during further cultivation. On the $7^{\text {th }}$ day, the AB-reduction level was significantly higher than the values, obtained on the $1^{\text {st }}$ day of culturing in all studied groups.

After 7 days of cultivation the MACG-discs, seeded with bone marrow SC, were histologically studied (fig. 5).
It was assessed that cells populate a macroporous sponge in a homotypic way independently on the injection method. No significant differences in the distribution and amount of bone marrow SC within MACG have been revealed. The cells formed friable and rather homogenous 3D net, made up of the elongated fibroblastic-like cells, usually in contact with each other.

After isolation and subcultivation in a monolayer for 4 passages the human bone marrow SC had the phenotype of mesenchymal stem cells [5, 14]: they expressed antigens CD29, CD44, CD105 and CD73, and were negative by the hematopoietic markers (CD34 and CD45). This property together with a possibility of induced multilineage differentiation makes $\mathrm{SC}$ an attractive object for connective tissue engineering within the carrier cells could proliferate, remaining in undifferentiated state and then could be induced to differentiate into the cells of bone, cartilage, adipose and other issues.

In the current study the polymeric sponges, based on the macroporous agarose cryogel, were used as a model of a cell carrier. Such carriers have a number of attractive characteristics for connective tissueengineering. They do not degrade in vivo, and have large interconnecting pores the surface of which is treated with gelatin improving cell adhesion [15]. Furthermore, MACG is enough transparent, that makes possible to carry out microscopic observations over the distribution and state of cells within the surface layers of carrier during in vitro cultivation.

The macroporous sponges, based on the agarose cryogel, have been used previously as a carrier for the pancreatic tissue engineering [13]. The study showed the possibility of MACG seeding with pancreatic islands and insulinoma cells. During the cultivation the pancreatic islands preserved the ability to secrete insulin and insulinoma cells were still able to proliferate. At the same time, the isolated pancreatic islands, cultured within MACG, have lost the insulin secretory response of pancreatic $\beta$-cells to the glucose stimulation. The non-uniform distribution of biological material (seeded to MACG directly by injection) could be a reason of the loss of the pancreatic cells functional activity. That method of seeding can cause cells accumulation in the place of injection that leads to their insufficient supply with oxygen and nutrients. 
In the current study the bone marrow SC were seeded into the MACG-discs in three methods. More efficient seeding of MACG was achieved by the stirring of cell suspension in the presence of carrier, and the intensive shaking (variant 2) ensured the maximum seeding of MACG. The application of "vacuum seeding", proposed elsewhere [7], led to less seeding of stromal cells into MACG. On the other hand, this variant allowed far better implementing of cell proliferative potential, estimated with Alamar Blue during the observation. This indicator integrally represents the activity of redox enzymes and has been successfully used by a number of authors in order to define the metabolic and proliferative activity of various cell types $[16,17]$. In the study [13] the comparative investigation of the proliferative activity of insulinoma cells when growing in the monolayer or within macroporous agarose sponges (used in the current work) has been made. It has been revealed that a proliferative potential of cells in the MACG-discs is higher than in monolayer culture.

In our study the levels of AB-reduction correlate with the seeding efficiency in MACG after twenty-four hours of the bone marrow SC cultivation, using the different methods of cell injection into the carriers. Considering the cells practically do not divide at first 24 hours of cultivation, the AB-test is thought to represent the metabolic activity of MACG-seeded cells. The increase in the AB-reduction level during further cultivation obviously reflects the proliferative activity of cells in the macroporous carrier. The proliferative activity of SC linearly increased for 7 days of cultivation at the variants 1 and 3 . In case of using the $2^{\text {nd }}$ variant, ensuring the maximum seeding of MACG, the AB-reduction level on the $4^{\text {th }}$ day slightly exceeded the values, received after the first days of cultivation.

It seems that at this mode of seeding, the cells are mainly located in the carrier surface layers. Under a high density of cells in the carrier periphery, the effect of contact-inhibition of proliferation, typical for fibroblast-like cells, probably occurred. Then, after 4 days of culture, the cells could migrate to less populated areas of MACG with further proliferation. The histological study has not revealed any significant difference in the cell distribution within the carrier on the $7^{\text {th }}$ day, using all variants of seeding.
Therefore, the data obtained indicate the availability of using the spongy macroporous agarose cryogels as a 3D carrier for the bone marrow stromal cells in the connective tissue-engineering. The represented data altogether show the possibility to implement all variants of the MACG-seeding with the bone marrow stromal cells. In any way of seeding the cells adhered towards the external and internal surfaces of pores, proliferated and demonstrated equal ability to reduce Alamar Blue on the $7^{\text {th }}$ day of cultivation.

Ю. А. Петренко, Н. А. Волкова, Е. П. Жуликова, Л. Г. Дамшкалн, В. И. Лозинский, А. Ю. Петренко

Выбор условий заселения полимерных макропористых губок стромальными клетками костного мозга человека

Резюме

Исследовали различные условия заселения полимерных губок на основе макропористого агарозного криогеля (МАКГ) стромальными клетками костного мозга человека. Использовали три варианта введения клеток в МАКГ: совместную инкубацию при постоянном перемешивании, интенсивное встряхивание и создание отрицательного давления. Результаты работы свидетельствуют о перспективности использования макропористых губок на основе криогеля агарозы в качестве трехмерного носителя для культивирования стромальных клеток при различных способах заселения клеток.

Ключевые слова: тканевая инженерия, стромальные клетки костного мозга, макропористые губки, агарозный криогель, заселение, Alamar Blue.

Ю. О. Петренко, Н. О. Волкова, О. П. Жулікова, Л. Г. Дамшкалн, В. І. Лозинський, О. Ю. Петренко

Вибір умов заселення полімерних макропористих губок стромальними клітинами кісткового мозку людини

Резюме

Досліджували різні умови заселення полімерних губок на основі макропористого агарозного кріогелю (МАКГ) стромальними клітинами (СК) кісткового мозку людини. Використовували три варіанти введення клітин в МАКГ: сумісну інкубацію при постійному перемімуванні, інтенсивне перемімування, а також створення негативного тиску. Результати роботи свідчать про перспективність застосування макропористих губок на основі кріогелю агарози як тривимірного носія для культивування стромальных клітин при різних способах уведення клітин.

Ключові слова: тканинна інженерія, стромальні клітини кісткового мозку, макропористі губки, агарозний кріогель, заселення, Alamar Blue. 


\section{REFERENCES}

1. Dang S., Gerecht-Nir S., Chen J., Itskovitz-Eldor J., Zandstra $P$. Controlled, scalable embryonic stem cell differentiation culture // Stem Cells.- 2004.-22.-P. 275-282.

2. Akselband Y., Moen P., Jr., McGrath P. Isolation of rare isotype switch variants in hybridoma cell lines using an agarose gel microdrop-based protein secretion assay // Assay Drug Develop. Technol.-2003.-1.-P. 619-626.

3. Пат. РФ № 2220987, 2001. Полимерная композиция для получения макропористого агарозного геля и способ его получения / В. И. Лозинский, Л. Г. Дамшкалн, Ф. М. Плиева, И. Ю. Галаев, Б. Маттиассон // БИ № 1, 2004.

4. Лозинский В. И. Криогели на основе природных и синтетических полимеров: получение, свойства и области применения // Успехи химии.-2002.-71, № 6.-С. 559-585.

5. Pittenger M., Mackay A., Beck S., Jaiswal R., Douglas R., Mosca J., Moorman M., Simonetti D., Craig S., Marshak D. Multilineage potential of adult human mesenchymal stem cells // Science.-1999.-284.-P. 143-147.

6. Петренко А. Ю., Мазур С. П., Петренко Ю. А., Скоробогатова Н. Г., Горохова Н. А., Волкова Н. А. Выделение и мультилинейная дифференцировка стромальных клеток из тканей плодов и взрослого человека // Трансплантология.-2007.-9, № 1.-С. 218-220.

7. Stosich M., Mao J. Adipose tissue engineering from human adult stem cells: clinical implications in plastic and reconstructive surgery // Plast. Reconstr. Surg.-2007.119.-P. 71-83.

8. Hong L., Peptan I., Clark P., Mao J. Ex vivo adipose tissue engineering by human marrow stromal cell seeded gelatin sponge // Ann.Biomed. Eng.-2005.-33.-P. 511-517.

9. Wang Y., Kim U., Blasioli D., Kim H. Kaplan D. In vitro cartilage tissue engineering with $3 \mathrm{D}$ porous aqueous-derived silk scaffolds and mesenchymal stem cells // Biomaterials.-2005.-26.-P. 7082-7094.

10. Takahashi Y., Yamamoto M., Tabata Y. Osteogenic differentiation of mesenchymal stem cells in biodegradable sponges composed of gelatin and $\beta$-tricalcium phosphate // Biomaterials.-2005.-26.-P. 3587-3596.

11. Choi Y., Park S., Suh H. Adipose tissue engineering using mesenchymal stem cells attached to injectable PLGA spheres // Biomaterials.-2005.-26.-P. 5855-5863.

12. Лациник Н. В., Грошева А. Г., Наровлянский А. Н., Павленко Р. Г., Фриденштейн А. Я. Клональная природа колоний фибробластов, образуемых стромальными костномозговыми клетками в культурах // Бюл. эксперим. биологии и медицины.-1987.-3, № -C. 257-284.

13. Bloch K., Lozinsky V. I., Galaev I. Yu., Yavriyanz K., Vorobeychik M., Azarov D., Damshkaln L., Mattiasson B., Vardi P., Vardi P. Functional activity of insulinoma cells (INS-1E) and pancreatic islets cultured in agarose cryogel sponges // J. Biomed. Mater. Res.-2005.-75A.-P. 802-809.

14. Dominici M., Le Blanc K., Mueller I., Slaper-Cortenbach I., Marini F., Krause D., Deans R., Keating K., Prokop D., Horwitz E. Minimal criteria for defining multipotent mesenchymal stromal cells. The International Society for Cellular Therapy position statement // Cytotherapy.2006.-8.-P. 315-317.

15. Lozinsky V. I., Damshkaln L. G., Bloch K. O., Vardi P., Grinberg N. V., Burova T. V., Grinberg V. Y. Cryostructuring of polymer systems. XXIX. Preparation and characterization of supermacroporous (spongy) agarose-based cryogels used as 3D-scaffolds for culturing insulin-producing cell aggregates // J. Appl. Polym. Sci.-2008.-108.-P. 30463062 .

16. Petrenko Yu. A., Gorokhova N. A., Tkachova E. N., Petrenko $A$. $Y u$. The reduction of Alamar Blue by peripheral blood lymphocytes and isolated mitochondria // Ukr. Biokhim. Zh.-2005.-77.-P. 100-105.

17. Gloeckner H., Jonuleit T., Lemke H. D. Monitoring of cell viability and cell growth in a hollow-fiber bioreactor by use of the dye Alamar Blue // J. Immunol. Meth.-2001.- 252.P. 131-138. 